\title{
VIDROS BLINDADOS E A SÍNDROME DO SILÊNCIO NO ABUSO - UMA ANÁLISE DOS REFLEXOS TRAZIDOS NA OBRA "O CASTELO DE VIDRO” DE JEANNETTE WALLS
}

\begin{abstract}
Ana Pontes ${ }^{1}$
RESUMO

O presente artigo estabelece relações entre o best seller "O Castelo de Vidro, memórias de uma família que aprendeu a criar finais felizes" com a síndrome do silêncio enquanto sintoma de violações à estabilidade e segurança de crianças e adolescentes. Tratado por parte da mídia como superação, sobram lacunas de análise sobre episódios de abusos na construção do silenciamento da protagonista e seus irmãos. Buscar conexões entre a ineficiência estatal na garantia do direito das crianças e adolescentes e suas aparentes escolhas em minimizar os episódios; refletindo sobre as razões pelas quais estes caminhos são trilhados é a contribuição pretendida.
\end{abstract}

PALAVRAS CHAVE: Abuso Infantil - Silenciamento - O Castelo e Vidro - Omissão Estatal - Memórias.

\section{ARMORED GLASSES AND THE SILENCE SYNDROME IN CHILD ABUSE: AN}

\section{ANALYSIS OF REFLEXES IN JEANNETTE WALLS' THE GLASS CASTLE}

\begin{abstract}
This paper establishes connections between the American best seller The Glass Castle by Jeannette Walls and the silence syndrome, as a symptom of violations of children's and teenagers' perceptions of stability and safety. Although treated by an important part of media as a tale of overcoming and forgiveness, many gaps remain about physical abuse episodes in the protagonist and her brothers' silencing. This work aims to contribute to seek connections between inefficiency in assuring children's and teenagers' rights and their apparent choices in cooperating and reducing episodes of abuse and to reflect on the reasons why those paths were taken.
\end{abstract}

Keywords: Child abuse. Silencing. The Glass Castle. State Omission. Memories.

\section{1- NOTAS INTRODUTÓRIAS SOBRE OS TRAÇOS MAIS PUBLICIZADOS DA OBRA E DELIMITAÇÃO DO OBJETO.}

A única regra era que tínhamos que voltar para casa quando as luzes dos postes acendessem. (...) Ela achava que era bom que as crianças fizessem o que queriam, porque aprendiam muito com os próprios erros. Não era uma dessas mães nervosinhas que ficam zangadas quando você chegava em casa todo sujo ou se cortava. Ela dizia que essas coisas tinham que acontecer quando você ainda era jovem. Uma vez, um prego velho fez um rasgo na minha coxa quando subi na cerca na casa da minha amiga. A mãe de Carla achou que eu devia ir para o hospital para dar uns pontos e levar uma vacina antitetânica.

1 Ana Pontes é professora de Direito da Universidade Federal Rural de Pernambuco. Mestra em Direito e Doutora em Educação pela Universidade Federal de Pernambuco, integrante da Comissão de Direitos Humanos da UFRPE. Endereço postal: Av. Bom Pastor, s.n., Boa Vista, Garanhuns. professoraanapontes@gmail.com 
-Foi só uma ferida superficial- declarou minha mãe após analisar o corte profundo. As pessoas hoje correm para o hospital toda vez que ralam o joelho- acrescentou. Estamos virando uma nação de mariquinhas. Dito isso, ela me mandou voltar para a rua brincar. (WALLS, 2007, 82,83)

Entre dezenas de episódios similares, e apesar da polarização de personalidades que a narradora imprime ao pai e à mãe, essa passagem de "O castelo de Vidro" demonstra com certa clareza um ponto de convergência na criação da protagonista e seus irmãos: a ideia de que os obstáculos - naturais ou acentuados pela negligência ou volitividade dos pais- tornariam as crianças mais fortes, adaptáveis e resilientes. A família Walls, fragmentada e fragilmente assentada sobre uma noção de heroísmo do pai e genialidade artística da mãe, se muda constantemente com seus quatro filhos Lori, Jeannette, Brian e Maureen por pequenas cidades dos Estados Unidos, sobrevivendo à custa da engenhosidade e espírito de sobrevivência das crianças, que demonstram excepcional capacidade de responder aos estímulos iniciais dos pais na construção de valores como a intrepidez, coragem e resistência. Com o crescimento do senso crítico das crianças, (no livro catalisado na narrativa de Jeannette) proporcionado pela sociabilização natural e pelo recrudescimento das necessidades materiais e emocionais desatendidas, é possível perceber a demolição gradual da fé dos adolescentes na capacidade de provisão e estabilidade dos pais, que após o afastamento dos filhos demonstram o esfacelamento do controle sobre suas vidas.

Descrito na orelha da obra como “...uma linda estória de trinfo sobre todo tipo de adversidade, uma narrativa emocionante sobre o amor incondicional por uma família que, apesar dos seus defeitos, deixou para Jeannette Walls uma rica herança: determinação para construir uma vida bem-sucedida", O Castelo de Vidro é facilmente recebido sem maior senso crítico como uma estória de redenção pelo amor ou resvalando para o fácil caminho da meritocracia onde o esforço desumano e individual de uma criança é capaz de vencer situações de abandono, violência e instabilidade. Pelo contrário. A protagonista não nada nessas águas e uma leitura atenta visualiza claramente que esta só resgata alguma normalidade em sua vida ao se mudar e finalmente residir junto com os irmãos em Nova York, após um período de pelo menos cinco anos distante dos pais. Nas entrelinhas é visível que mesmo sua ascensão econômica se dá e se mantém através do casamento (quando, por exemplo, a irmã mais nova vai presa, ela descreve claramente que obtivera o dinheiro da possível fiança junto ao marido, mesmo já sendo jornalista há anos). Enquanto o crescimento profissional por sua vez se dá a partir da conclusão de um curso superior, ainda que a mesma já trabalhasse na área pouco tempo depois de chegar à cidade). $\mathrm{O}$ paradoxo estabelecido por se tornar jornalista especializada em 
expor bastidores de colunáveis e suas misérias pessoais não lhe coloca magicamente no grupo das pessoas bem-sucedidas, ainda que lhe melhore a evidência profissional; e sim lhe reforça o sentimento de que sua origem e experiências precisam ser escondidas para que passe uma suposta credibilidade de uma normalidade que sofrera para performar.

Este artigo portanto traz como problema a discussão de dois aspectos importantes: a visão discutível de sobreviventes de abusos intrafamiliares como pessoas excepcionalmente fortes cuja estória pode servir para consumo e reforço da necessidade humana de contos de fadas com finais apaziguadores; bem como tem como objetivo pontuar o silenciamento da "personagem" junto ao eu-real da autora da autobiografia ao longo da obra e as contribuições da concepção de "vitória sobre os destroços" na ânsia humana de heróis e heroínas no silenciamento do abuso intrafamiliar. Esta discussão se insere na linha temática das relações entre direito e literatura, esperando-se traçar algumas contribuições na gama da psicologia jurídica, em especial sobre estratégias de sobrevivências de crianças e adolescentes sobreviventes de abusos físicos e psicológico de variados matizes.

O Castelo de Vidro, uma autobiografia de uma jornalista estadunidense, atingiu forte sucesso editorial em função de diversos motivos de identificação evidente e outros nem tanto. Parte deles se deveu a alguma proeminência profissional da escritora como repórter de famosos, embora não detivesse tanto destaque em sua área como se pode pensar. Na verdade, o espaço atingido pelo livro a projetou mais do que sua carreira anterior revelando os bastidores das celebridades. De fato, parte inicial do sucesso se deu pelo elemento surpresa da repórter especialista em esquadrinhar passados possuir um passado intrigante, somado ao contraste do aspecto pessoal que Jeannette buscou imprimir por diversos anos, com vestuário excessivamente sóbrio e modos predominantemente contidos e aristocráticos, que se mantém mesmo após a popularização da obra sobre seu passado de miserabilidade econômica. O efeito que a jornalista causa nas centenas de entrevistas concedidas, aumentadas em 2017 pelo lançamento do filme baseado na obra, ajuda a aumentar a curiosidade e ela demonstra consciência disto. Outros pontos menos óbvios inserem-se na atração atávica de autobiografias de caráter superacional, na qual certamente se inscreve a obra. A própria Jeannette Walls a certa altura da narrativa admite que era fã de estórias de superação e registra a relevância desta influência: "Lori era a leitora mais obsessiva. Ela adorava estórias fantásticas (...). Eu não queria ser transportada a um outro mundo. Os meus livros preferidos tratavam de pessoas que lidavam com as dificuldades da vida" (WALLS, 2007,56). E na continuação de seu comentário é possível perceber que ela via as obras do gênero, como As Vinhas da Ira e Laços Humanos 
como um caminho possível: "achava que a Francis Nolan e eu éramos idênticas (...) O pai dela lembrava, sem dúvida, papai. Se Francis via o lado bom do pai dela, mesmo que a maioria das pessoas o considerassem um bêbado imprestável, talvez eu não fosse uma burra completa por ter fé no meu" (WALLS, 2007,56).

O caráter inspiracional é inteligentemente sintetizado por uma crítica do The New York Times destacada na contracapa das edições ao lembrar que "as autobiografias são os nossos contos de fadas modernos. A narradora encara o desafio de compreender, perdoar e até mesmo amar a bruxa. Os leitores ficarão maravilhados com a inteligência e a resistência das crianças Walls".

A reflexão, porém precisa ser muito menos rasteira que uma obra no estilo motivacional. Ao contrário, a visão limitada de que trata-se de um caminho para a superação da pobreza, da negligência, de sucessivos abusos e ao final a beleza do perdão resume indevidamente uma trajetória acidentada e sofrida para este aparente apaziguamento e minimizada pela ideia inclusive sugerida pela confusa mãe da autora de que "se não deu certo ainda é porque não chegou ao final". Para Mary Charlene, a criança falecida rapidamente mencionada em um dos capítulos e de temática proibida na alegria delirante da família nômade e sem freios; ou para Maureen, a caçula usuária de drogas e-ou com transtornos mentais agudos, mesmo o afeto esforçado e as tentativas de cuidado das demais crianças não parecem ter chegado a tempo.

\section{2- A CONSTITUIÇÃo FAMILIAR DA FAMília WALLS E A LENTA CONSTRUÇÃO DE UM CONCEITO DE INATINGIBILIDADE E FORTALEZA, PERMEADO POR CONTRADIÇÕES.}

A despeito da arbitrariedade na escolha dos episódios e da narrativa sobre eles que caracterizam as obras biográficas, é perceptível que Jeannette projeta sobre o pai um ideal muito comum de intrepidez e mesmo audácia texana. Em entrevistas relativas ao livro a escritora assume a dificuldade que encontrou da aquiescência para a publicação da obra pela família, vez que envolvia não apenas a revelação da desfuncionabilidade dos pais, mas a episódios de abusos sexuais de si mesma e dos irmãos. Comentando a rejeição da ideia da publicação pela irmã mais velha, em especial, ilustradora em Nova York, ela agradece a inesperada concordância pela mãe (ainda que evidentemente portadora de transtorno psiquiátrico leve, possivelmente bipolaridade) e o apoio recebido pelo irmão Brian, hoje policial no Brooklin. De Brian, a quem 
ela agradece prioritariamente, sobram as mais comoventes narrativas de fraternidade e identificação, ficando visível a conexão, por outro lado, de Lori com a mãe, a quem considera uma incompreendida com o mesmo fervor que a autora fantasia sobre os dons e afetividade do pai. A Brian, aparentemente, sobra girar em torno das irmãs mais velhas, interessado e orgulhoso de suas capacidades intelectuais, embora fique subentendido no livro que após uma breve fase de bom desenvolvimento escolar, ele volte seus interesses para o desenvolvimento físico. De poucas palavras, Brian parece ter, diante da verborragia de Jeannette e da mãe; conclusões raras e bem postas, fruto da intensa observação do cenário. Maureen, a caçula, que apesar de nascida na pior fase da família Walls, cresce aparentemente sob condições menos precárias posto que adotada informalmente pelos vizinhos, passa frequentemente ao largo da narrativa, excetuando-se quando encarna o elemento que separa a família pela última vez no tribunal. Os pais de Jeannette, por sua vez, constantemente são retratados como geniais mas inconsequentes, onde a amorosidade é invocada permanentemente para suavizar comportamentos de graves negligências, havendo raros episódios de agressão voluntária e cruel. Na maior parte do tempo Rex e Rosemary encarnam dois adolescentes obcecados pelo interesse mútuo, sobrando pouco espaço para os filhos, que por vezes são vistos como argila moldável para suas teorias filosóficas, educacionais e desejo de aventura, o que os romantiza durante muito tempo na visão das crianças, ansiosas por imitá-los no desprendimento e coragem, suportando as intempéries e mantendo uma atitude de constante bom humor temperado com o desprezo pelas opiniões alheias. Não são poucos os episódios porém, que Rosemary e Rex se "livram" das crianças quando estas não cabem no esquadro (numerosas situações de os deixarem presos em carros enquanto vão a bares, ou serem encerrados em baús de caminhonetes ou mesmo esquecidos temporariamente). Na descrição de Jeannete, o pai é desenhado como "um gênio", "especialista em matemática, física e eletricidade" e apaixonado por inventar coisas, com habilidades variadas de marcenaria e mesmo arquitetura, fazendo plantas baixas detalhadas. Uma característica evidente na obra é a paixão onipresente pela leitura, com cenas como a discussão empreendida pelo pai já bastante arruinado pelo álcool e em situação de rua sobre a Teoria do Caos, ou seu interesse em obter previamente a lista de livros do semestre universitário da filha já adulta para lê-los na biblioteca pública entre um jogo de pôquer e outro e debater os assuntos com Jeannette. A mãe, por sua vez, goza de menos admiração da filha, apesar da constância das reflexões filosóficas marcantes. Da filha parte porém o reconhecimento que, apesar de indisciplinada e em constante lassidão e comportamento egóico, a mãe era inspirada como professora nas poucas vezes que decide 
trabalhar para evitar nova visita do Serviço de Proteção Infantil e mesmo a autora revela uma indisfarçável admiração por análises cirúrgicas sobre situações e fatos quando todo o exterior caótico da mãe a sinaliza como confusa ou entregue. É visível que a descrição mais entusiasmada da mãe remete-se à juventude de Rosemary, na descrição do pai como uma moça que mergulhava em rios de penhascos e usava um desafiador batom vermelho. Considerando que o pai tinha por hábito contar estórias de valentia como piloto da aeronáutica para os filhos dormirem, a projeção de Jeannette é direcionada à época que ela imagina que o pai teria uma companheira à altura, corajosa também para encontrar soluções e trabalhar pela estabilidade da casa, e não apenas "viciada em adrenalina", como o bordão que a mãe lhe responde sempre que a filha pede-lhe mais estabilidade ou adequação social. A transferência de responsabilidade notável da mãe sobre necessidades básicas como alimento ("não posso cozinhar algo se ninguém providenciou algo para ser cozinhado", responde certa vez à fome da prole, e vai pintar) é um exemplo. Percebe-se, na verdade, que a mágoa da protagonista se enraíza pela omissão permanente da mãe nas mais diversas situações, inclusive de abuso dela e dos demais. O olhar seletivo da autora entretanto parece absolver o pai, ignorando que ele também toma conhecimento dos episódios, tendo inclusive participado de forma ativa em um deles.

Por variadas oportunidades, Rex e Rosemary Walls forçam suas crianças a viverem situações de risco como forma de cultivar o destemor que consideram um valor, desde que que não interfiram na sua trajetória de negligência. Mergulhos forçados na água ao lado do pai, incentivo a tratarem feridas e acidentes em casa e desinteresse por conflitos escolares, por exemplo. As características de genialidade ou de coragem, todavia, são exaltadas e celebradas pela família. Os pais ensinam braille, pintura, discutem filosofia e literatura com a prole desde muito cedo, sob as condições mais desapegadas ou indiferentes. Por doze vezes na obra, abandonam casas inteiras com móveis, roupas, brinquedos e animais, para enfiarem poucos pertences no carro e com quase nada estabelecerem-se em outra cidade na manhã seguinte. Sobretudo ensinam que precisam ser fortes, minimizar ou silenciar conflitos psicológicos e estarem sempre dispostos encarar a vida como uma interminável aventura onde conforto, segurança ou limpeza sejam secundários. Rex Walls, todavia, é desenhado como o grande protagonista da infância dos Walls. Eventualmente brinca com as crianças da rua e desperta nos filhos o orgulho do pai destemido e participativo. Leva-os a invadir um zoológico e acariciar um tigre, varar noites ao relento no deserto aprendendo sobre astronomia, mirar uma pistola, manusear arco e flecha e atirar facas à distância. Descrevendo as estórias romanceadas sobre si mesmo com as quais embalava os filhos, Jeannette observa: 
Papai era sempre o melhor lutador, voava mais rápido e apostava mais espertamente que qualquer outra pessoa nos seus contos, No seu caminho, ele salvava mulheres e crianças, e até homens que não fossem tão fortes e inteligentes. Papai ensinou os segredos do seu heroísmo- mostrou como agarrar um cão selvagem e quebrar seu pescoço, e onde atingir um homem na garganta para matá-lo com um golpe só. (WALLS, 2007, 40).

Rosemary também é descrita generosamente a princípio, contudo com uma inteligência que vai passando de audaz ("a maioria das pessoas acha difícil sobreviver no deserto, mas mamãe era mestra") a cada vez mais nublada pelo fracasso. É perceptível o declínio de Rosemary com as prolongadas ausências de Rex e a necessidade de assumir sozinha a manutenção da casa, da qual ela se recusa frequentemente, muitas vezes culpando a existência das crianças pelo insucesso profissional como artista e a necessidade de trabalhar como professora primária. Essa erosão da admiração da filha pela mãe, ampliada nos momentos em que a mãe chora seu fracasso ou se recusa a sair da cama permeia toda obra, com rápidos e frágeis resgates mínimos nos momentos em que ela simplesmente parece mais disposta, mesmo que o caos permaneça. A insatisfação com os momentos derrotistas da mãe são tão fortes que recebem bem menos atenção que um número considerável de episódios de contradições políticas como desprezo a classes baixas (quando eles mesmos vivam em situação de pobreza) ou rechaço ao consumo enquanto furtam magazines e fraudam caixas eletrônicos, que poderiam chocá-la, posto que ambos se colocam como progressistas, revolucionários e de esquerda. Em três momentos diferentes da narrativa, por exemplo, vê-se a incoerência sobre o discurso de não julgar pessoas por classe ou origem:

\begin{abstract}
A mamãe estava sempre abraçando os seus alunos e reforçando como eles eram maravilhosos e especiais. Ela dizia para as crianças mexicanas nunca deixarem que os outros dissessem que não eram tão boas quanto as outras crianças brancas. Declarava às crianças navajos e apaches que elas deviam ter orgulho da sua nobre herança indígena. Os alunos considerados problemáticos ou mentalmente lentos começaram a melhorar o rendimento. Alguns seguiam a mamãe pra cima e pra baixo. (WALLS, 2007, 101)
\end{abstract}

Pouco antes, no nascimento de Maureen, a indecisão sobre o nome do bebê gerara o seguinte comentários: “...eu queria que fosse Rosita como a menina mais bonita da minha sala, mas a mamãe disse que era mexicano demais". Sendo interpelada se não era preconceito, responde: “questão de precisão na hora de escrever a etiqueta”(WALLS, 2007,68).

Dessa erosão da admiração da mãe, finalizada pelo afundamento no alcoolismo do pai, que em crescentes momentos de violência física, emocional e patrimonial se desconstrói diante 
dos filhos cada vez mais permeáveis a influências externas e outras possibilidades de comparação (casas de amigos com calefação, escola disciplinadora, mas que fornecia comida quente, rejeição social permanente pela sujidão do grupo). Sintetiza com qualidade a autora em um comentário quase descompromissado ao longo do texto: "nessa época, parecíamos ser um estorvo mais pesado do que antes. A Lori já era uma adolescente, e em poucos anos, o Brian e eu também seríamos. Eles não podiam mais nos trancar no fundo de uma caminhonete, nem no colocar para dormir em caixas de papelão" (WALLS, 2007,188)

\section{3- DOS ABUSOS FÍSICOS DIVERSOS, AUSÊNCIA ESTATAL E A ASSOCIAÇÃO COM A FRAQUEZA COMO ESTRATÉGIA DE REFORÇO DA SÍNDROME DO SEGREDO}

Enquanto as construções irreais de uma criança são menos difíceis de desarmar do ponto de vista do acompanhamento psicológico, mais frágeis são as possibilidades de êxito de estórias completas e detalhadas sobre abusos físicos e sexuais intra familiares. A própria percepção desta trava da fala só é percebido tardiamente, quando a própria concepção de que o episódio foi uma violência se instala. Obviamente tratamos dos abusos cometidos sem imobilização física ou ameaça de dano físico direto. É fato, porém que a violência acompanha o sentimento de revitimização particular, que ocorre quando a vergonha é a consequência direta do sentimento pouco racional da vítima de que foi cúmplice do abuso, que contribuiu para ele. Na visão de que as pessoas adultas sabem o que é correto e a gravidade das vivências das mais jovens, as vítimas, como no livro, tendem a graduar a importância do abuso pelo grau de relevância que os adultos em que confiam dão ao episódio. Enquanto internamente ocorre o debate entre a gradação de importância conferida pelos adultos de sua confiança e o sentimento de violação, lentamente se instala a parte perversa da reação que vem a dar origem à síndrome do silêncio, o medo de que deixem de gostar delas, todos eles: como na fala de uma sobrevivente "os que abusam de nós e os que parecem nos proteger mas na verdade protegem quem nos abusou" (SIA, 2000). Se o abuso acontecer muito cedo dificilmente a criança aprenderá a distinguir uma coisa e outra e dependerá ainda mais dos adultos para avaliar. Tanto pior quanto mais próximo for o abusador. Para não entristecer a mãe. Para não horrorizar o pai. Para não fragmentar a família.

Em O Castelo de Vidro, a despeito dos diversos abusos de narrativa descomprometida com as consequências dedutíveis ao longo do desenlace dos personagens 
por um leitor ou leitora atento, é possível acompanhar por poucas páginas o abuso de Brian pela avó paterna, tornado visível pelo testemunho das irmãs mais velhas, que lhe dão credibilidade, desconstruída pelos pais que pela dependência econômica da mesma, amputam a fala dos filhos com um violento discurso sobre independência e autodefesa. É notável perceber o quanto o caso específico do irmão criança machuca a personagem, que por sua vez dá menor importância narrativa ao abuso que sofre do jovem tio, menos ainda de um desfile de abusos por estranhos, garotos da escola, patrão e mesmo um homem indicado por seu pai.

O silenciamento que apontamos começa a ficar visíveis no último terço da obra, quando os episódios anteriores de silenciamento fortalecem na narradora o mecanismo instalado: redução do fato a algo corriqueiro, ênfase na percepção dos pais ou na superação do episódio. Após tantos casos, somados ao franco desinteresse dos pais pela narrativa das vítimas à qual eles associam à fraqueza de espírito, a visão da personagem está tão alterada que não estabelece maior relação entre o abuso sofrido pela irmã que precisa pedir carona na estrada para conseguir chegar a uma disputa de bolsa universitária e não passa na prova. Ao descrever o fato a autora o resume em duas frases: "no caminho ficou perturbada quando o caminhoneiro que lhe deu carona tentou abusar dela. Chegou com quase uma hora de atraso e não passou". Logo em seguida usa um parágrafo inteiro para destacar uma reflexão da mãe sobre a possibilidade de "autossabotagem" de Lori por não conseguir finalizar as etapas para obtenção da vaga na universidade: “mamãe apoiava o projeto de Lori de ir pra Nova Iorque e vivia dizendo que ela própria tinha vontade de se mudar pra lá”. Lori reune um portfólio com seus desenhos e pinturas, mas pouco antes do prazo da apresentação dos documentos, derrama um bule de café nele, "o que fez a mamãe comentar que talvez Lori tivesse medo do sucesso". (WALLS, 2007, 189, 190).

As crianças Walls vivem com alimentação escassa, pai alcoólatra e oscilando entre ausente ou violento, e uma mãe com evidentes transtornos psiquiátricos não diagnosticados e tratados. Os pais esforçam-se para evitar maiores registros dos filhos e mudam-se constantemente, o que dificultaria a identificação, ainda assim mas a ausência estatal é notória. A despeito de denúncias de alguns vizinhos, a situação segue incólume sob os olhares de professores e outros profissionais que cruzam o caminho da família disfuncional. Apenas por uma oportunidade o Serviço de Proteção ao Menor vai à casa da família, quando a decadência da própria casa cercada de lixo incomoda os vizinhos. É a única vez que a família é contatada e permanece no endereço, mas o funcionário simplesmente não regressa. 
Observa Tilmam Furnis $(1993,102)$ que o abuso sexual da criança é um problema maior do que o esforço, as capacidades e as responsabilidades que uma única profissão consegue abranger. Ele é uma questão verdadeiramente multidisciplinar e metassistêmica. Na trajetória de Jeannette Walls, as tentativas pouco eficientes sua e dos irmãos de disfarçar a situação de vulnerabilidade que viviam tiveram como "apoio" para aumentar essa barreira uma omissão generalizada de familiares, vizinhos e professores. A visita do serviço de proteção por sua vez demonstra a visão meramente fiscalizatória e não acolhedora do estado na investigação superficializada de uma denúncia de negligência infantil: Jeannette põe-se a mentir da forma mais eloquente que consegue, enquanto vislumbra a visita do funcionário como uma punição para a autonomia dos seus pais e uma forte ameaça à separação de seus irmãos, que constituem sua base mais sólida de companheirismo e de singela estabilidade, diferentemente dos pais a quem a pergunta "alguma vez já deixei vocês na mão?" jamais pode ser respondida com outra escolha que não a negativa.

Enquanto a escritora dispende páginas seguidas para descrever entusiasticamente as "caçadas" amorosas empreendidas com o pai em busca de demônios imaginários, e posteriormente após o primeiro ataque noturno por um estranho, as "caçadas ao tarado nojento", resume em meia página o abuso sexual do tio e gradualmente em menos linhas os abusos posteriores do patrão. Além do reforço da visão abstrata que Jeannette e os irmãos carregavam da necessidade de ser forte sob quaisquer circunstâncias, percebe, embora não narre nem estabeleça esta ligação, de que não haverá um pai herói nem uma mãe desbocada para defendê-la quando a fala sobre o abuso atingir qualquer membro familiar, que possa gerar desequilíbrio íntimo no status quo. Percebe cedo a autora que a grande diferença entre o abuso sexual intra familiar e o extrafamiliar se dá basicamente pelo conceito psicológico da síndrome do segredo.

Frequentemente quando o abuso sexual ocorre fora do lar, ou tem como abusador alguém não próximo à família, há a possibilidade de providência imediata, na grande maioria das vezes, denunciar o agressor, dando-se crédito à denúncia da criança. O outro é o mal, o outro deve ser combatido. Quando o outro, porém, está enredado na teia familiar, as "ponderações" se multiplicam.

Quando o agressor é o pai biológico, padrasto, pai adotivo, tio, avô, irmão, na grande maioria dos casos, se concentra o esforço familiar na busca de se manter a "normalidade" que é ameaçada com a revelação. Observa Maria Rosi Borba (BORBA, 2008) que o fenômeno que psicólogos chamam de síndrome de segredo e que leva a não 
revelação, às vezes, por longo período, ocorre por vários motivos que vão desde a culpa que a criança carrega por ter participado da interação abusiva, até ao medo das consequências da revelação, como desintegrador do núcleo familiar. Outra premissa que não se embasa em fatos da realidade é a assertiva de que os cuidadores não abusivos sempre acreditarão na revelação do abuso sofrido por parte da criança. A negação psicológica e a incapacidade de acreditar na revelação do abuso sofrido ocorre com mais frequência do que um leigo é capaz de supor, e leva a criança vitimizada a crer que a sua história não interessa e que os adultos não se preocupam com ela.

A primeira vez que Jeannette acorda com um homem alisando suas parte íntimas e é salva por sua própria resistência e pela interferência do irmão Brian, demonstra claramente não ter noção do perigo existente caso o agressor não tivesse decidido fugir. Celebram sua coragem de nove e dez anos (na verdade, sorte) e ao contarem posteriormente aos pais, recebe de Rex Walls um incentivo à nova caçada encenada com os filhos menores para localizar o agressor. Quando Jeannette sugere que passem a fechar as janelas da casa quando fossem dormir, recebe dos pais a resposta de que o ar fresco era essencial, tanto quanto não se render ao medo (WALLS, 2007,137). Mesmo após o dramático abuso de Brian, que sugere à escritora que o alcoolismo do pai, bem como o comportamento errático paterno pode ter sido fruto de abuso similar, a mãe de Jeannette não dá maior importância à narrativa do abuso da filha pelo tio, filho da avó agressora. Pelo contrário: usa da sua habilidade retórica para confundir a filha sobre a gravidade do fato, jogando sobre os ombros da adolescente decidir a validade do episódio:

Senti a mão do Stanley se aproximando e roçando minha coxa. Olhei para ele, mas ele ficou olhando para as musas da televisão tão intensamente que eu não consegui ter certeza se ele estava fazendo aquilo de propósito, e por isso afastei sua mão sem dizer nada. Poucos minutos depois, a mão veio se esgueirando de novo. Olhei para baixo e vi que a calça do tio Stanley estava com a braguilha aberta, e que ele estava se tocando. Tive vontade de bater nele, mas fiquei com medo de me encrencar que nem a Lori, depois de dar um soco na Erma, por isso corri até a mamãe.

-Mãe, o tio Stanley tentou abusar de mim.

-Você deve estar imaginando coisas.

-Ele passou a mão em mim! E ficou se masturbando!

Mamãe balançou a cabeça e pareceu preocupada.

-Coitado do Stanley, ele deve estar tão sozinho.

A narrativa então segue demonstrando a perda de autoconfiança de Jeannette na própria narrativa. Quando a mãe a pergunta se ela está bem, ela encolhe os ombros e assente 
com a cabeça, já imitando parcialmente a postura de desvalorização do ocorrido diante da mãe. Rosemary segue, em argumentos questionáveis, descritos pela jornalista: "ela disse que abuso sexual era um crime de percepção. Se você não achar que está machucada, então não está. Tanta mulher faz tempestade num copo d'água por causa dessas coisas. 'Mas você é forte e não precisa disso'. E voltou a fazer palavras cruzadas"(WALLS, 2007,236). Jeannette, no entanto, apesar da aparente concordância com a minimização do caso, desiste de tomar banho no único local disponível, a casa do tio, receosa de que sua "fortaleza" fosse compreendida com interesse no prosseguimento do abuso.

Para o abusador as síndromes de segredo e de adição encontram-se interligadas e compõem o processo de interação abusiva. Não restam dúvidas que o vitimizador tem consciência de que o abuso sexual é prejudicial à criança e, apesar disso, o abuso acontece. $\mathrm{Na}$ visão dos terapeutas, o abusador sexual age em relação à criança como os dependentes de entorpecentes agem em relação à droga.

É factível notar que, ao contrário do processo de drogadição, em que o polo ativo é ocupado pelo dependente e o polo passivo pela substância da qual depende, no abuso sexual o polo passivo é preenchido pela criança, "coisificada" e pronta para ser consumida. Os abusadores intra familiares da obra tinham todos vício grave em álcool, o que não confunde, porém, com os abusos perpetrados. Assim, se instala uma relação onde o abusador se transforma em um dependente da criança abusada, e dela necessita, inclusive para que guarde o segredo sobe o abuso ocorrente. Nos casos de abuso sexual intra familiar é imprescindível relembrar que a criança sofre, normalmente, em seu meio familiar, pressão psicológica para não romper a síndrome do segredo. Maria Rosi Borba assinala que "ao questionar uma criança vítima de abuso sexual, especialmente o intra familiar, o magistrado deve transmitir à vítima a sensação de que a sua história lhe interessa e que não teme conhecê-la. Na busca de preservar a criança, muitos juízes evitam questioná-las, na intenção de protegê-las. Os terapeutas afirmam que ao agir assim, o magistrado passa à criança a impressão de que sua história não lhe interessa e que a criança não tem autorização para romper o segredo" (BORBA,2008). Em parte, percebe-se, a vítima cresce e encontra-se diante de magistrados metafóricos.

É interessante pensar, portanto, o quanto a estória que Jeannette repete centenas de oportunidades em programas televisivos e na divulgação do filme baseado na mesma tem um roteiro previsível, que dá às pessoas o que elas conseguem digerir e não suas partes intragáveis. Como uma criança que aprendeu a obter acolhimento e reconhecimento pela 
superação, fica o questionamento até que ponto os testemunhos de abusos e os próprios abusos foram silenciados - novamente - pela obrigação de no passado ser forte, e no presente ser exemplo de superação. O final precisa ser feliz. E é muito difícil de encará-lo se deslocarmos a visão da elegante ruiva Jeannette para uma vítima de incesto, porque isso nos obrigaria a lembrar que o abuso sexual intra familiar existe, e esfacelaria novamente o final feliz de que, apesar de todas as agruras, a família Walls conseguiu permanecer unida e seus pais foram heróis heterodoxos.

Contribuições sobre a temática podem ser encontradas na obra de Tilman Furniss (2003) especialista que colaborou com órgãos como ONU e OMS. Furniss defende que um ato de violência sexual intrafamiliar se baseia em dois sustentáculos: a síndrome da adição e a síndrome do segredo. As duas síndromes se interligam de tal maneira que se tornam um mecanismo de evitação da realidade para o abusador. Este segredo, inclusive, pode ser o sustentáculo de uma dinâmica familiar doentia, mas que se estabelece utilizando a violação como fator de manutenção. No caso da obra, por exemplo, é perceptível, que, apesar de reiteradas afirmações de que a prole seria um peso para a carreira da mãe matando suas possibilidades de êxito artístico, ao ver-se, enfim, livre das responsabilidades maternas, com a migração dos filhos para Nova York, tanto a mãe quanto o pai afundam-se ainda mais, demonstrando claramente que era a força, coragem e tenacidade da prole que os sustentava e não o contrário.

Por outro lado, a rede de apoio às situações de abuso são bastante fragmentadas em geral. Na "melhor" das hipóteses, a maioria das redes estatais em diversos países apresenta dificuldades de oitiva e exame respeitosos. É comum que tenha como consequência o afastamento da criança e não do abusador, punindo a criança e indiretamente a responsabilizando pela "destruição" da união familiar, como claramente teme Jeannette na única visita do Serviço de proteção ao Menor. Frequentemente é a criança que perderá o convívio com irmãos e familiares não abusivos caso abrigada e sua situação de individualidade é sacrificada pelo abrigamento coletivo. Outros laços podem ser rompidos, como a escola de origem e amigos próximos ao endereço, me especial em situações de risco. Não existem, especialmente no Brasil, mecanismos seguros nos quais a criança se sinta acolhida, não revitimizada e que privilegie o afastamento do agressor, não da vítima.

Um dos aspectos que fortalece o abuso é a sensação de cumplicidade em que a criança é colocada. Na obra, após a manipulação do tio Stanley e diante da indiferença da mãe, Jeannette "decide" ficar sem usar o único banheiro disponível para que ele não 
interpretasse que o uso significasse consenso para novos ataques. É chocante porque dá a impressão de que ela já compreendeu que outras pessoas sugeririam a co-responsabilidade dela no episódio, e mesmo fala dele com frieza, já minimizando o fato. Fairman, observa que crianças pouco vigiadas, deixadas por sua própria conta ou que têm carências emocionais e afetivas são as mais vulneráveis e constituem provavelmente o alvo preferido (FAIRMAN, 2004, 73). É um retrato acabado das crianças Walls, que apesar de seus pais pouco trabalharem, estavam constantemente sós.

O lamentável é que a ausência de credibilidade da criança se vê no âmbito familiar e no sistema investigativo. Ainda que, segundo Furniss, dificilmente uma criança suportará demasiado tempo sem tentar relatar a um familiar sobre a violência que está vivendo, "frequentemente encontramos crianças que dizem ter tentado contar às suas mães, a outros membros da família ou a pessoas de fora, apenas para não serem acreditadas, serem chamadas de mentirosas e serem castigadas" (FURNISS,1993,105). Nesse sentido, das piores consequências que contribuem para a síndrome do segredo é o prosseguimento do convívio com o agressor, a reincidência do abuso e a certeza adquirida pela criança de que seu caso é desimportante, como ocorre, por exemplo, no abuso do pequeno Brian pela avó ou na percepção de Jeannette que seu pai a usava como isca, construindo propositalmente a noção para outros homens de que ela seria sua namorada.

Observa Tilman Furniss que comumente a imposição do silêncio se dá sob a ameaça de ser a criança responsabilizada pelo "término do casamento dos pais, desintegração familiar, prisão do abusador, expulsão da criança do lar, sua morte ou mesmo do próprio descrédito da palavra do menor." (FURNISS,1993,104).

Um dos desafios mais candentes é o fato de que crianças que sofrem abusos sexuais e desamparo reagem de formas diferentes. Muito frequentemente o imaginário comum constrói uma ideia da vítima calada, retraída, pudica ou assexuada, por exemplo. Todavia a dissociação é uma resposta bastante comum, como estratégia de adaptação psicológica à situação intolerável. Observa Furniss que uma defesa inconsciente do menor pode levá-lo a "estados alterados de consciência para desligar-se da dor ou para dissociar-se de seu corpo, como se estivesse olhando à distância para a criança que está sofrendo o abuso" (FURNISS, 2003, 78). Acrescenta Zavaschi, que "trata-se de dissociação, o mecanismo que separa o corpo da psique, utilizando estados alternados de consciência para expulsar a dor que se expressa através de sintomas dissociativos” (ZAVASCHI, 2002,141). 
Uma reação comum é que passem a fingir que não são elas que estão sofrendo a violência, na busca de sobrevivera abusos que podem perdurar por anos. E são as sequelas que causam problemas emocionais na fase adulta devidos aos momentos de terror sofridos na infância. No folheto "Características de um Sobrevivente e Efeitos do Abuso Sexual na Infância do Grupo de Apoio Sobreviventes de Incestos Anônimos", alguns depoimentos ajudam a dimensionar as consequências desta trajetória, como "Muitas de nós tinham um conceito negativo de si mesmas. Aprendemos a acreditar que estávamos destinadas a negar a nós mesmas. Nós nos sentimos usadas e nos víamos como não tendo nada para oferecer além de, talvez, sexo." Em outro depoimento sobre danos psicológicos, uma das depoentes discorreu mais largamente: "nos sentimos enraivecidas e exploradas, dependentes e impotentes, ansiosas e embaraçadas, ofendidas e solitárias”. Notando as consequências a longo prazo na personalidade adulta, continua:

Às vezes, bloqueávamos nossos sentimentos, usando máscaras e fazendo brincadeiras. Nós negamos, minimizamos ou diminuímos nossa vitimização. Éramos despreocupadas, retraídas, esquivas, super ativas, delinquentes, promíscuas, dependentes...cada uma de nós encontrou sua forma de tentar não sentir. Nós dirigimos nossa raiva para o endereço errado $\mathrm{e}$ frequentemente a expressamos inapropriadamente. Algumas de nós sentimos raiva de outros membros da família por não nos protegerem. Nós nos sentimos confusas com nossas necessidades e nos culpamos por ter necessidades. Algumas de nós se sentiram inadequadas ao se relacionar com os outros; nós nos retraímos e nos isolamos e éramos incapazes de deixar que os outros se aproximassem.

Observa-se na análise dos depoimentos da SIA que algumas características são recorrentes em vítimas mulheres: a dificuldade de dizer não e negar ajuda aos outros, tornando as vítimas vulneráveis à exploração alheia. Uma das razões para este comportamento implica a própria percepção da pessoa sobrevivente de que a ajuda e proteção lhe fora negada e esta não pode suportar imaginar que fará o mesmo. Outra a dificuldade de distinguir entre amor e sexo e a crença que apenas este seja uma forma genuína de afeição ou que pode receber:

Algumas de nós acreditavam que o que nos estava acontecendo não era fora do comum, enquanto outras acreditavam que possivelmente eram as únicas a vivenciar este tipo de contato sexual. Algumas de nós aprenderam a usar sexo como a única forma de obter afeição ou de manter um relacionamento, enquanto outras aprenderam a sentir que sexo é sujo e principalmente um ato físico. Frequentemente tínhamos nojo de nossos corpos e dos corpos dos outros, ou éramos incapazes de distinguir entre amor e sexo. 
A mais marcante e repetitiva característica porém é a convicção da culpa pelo ato, verbalizada por inúmeros depoimentos e sintetizado por um deles que explicita: "o que eu fiz para que isso acontecesse comigo?"

\section{4- ABUSOS EM SEGUNDO PLANO NA REDENÇÃO DA AUTORA-PERSONAGEM: PORQUE PRECISAMOS DE HEROÍNAS SEM RUÍNAS INTERNAS.}

Jeannette incorpora a self made woman celebrada na cultura estadunidense, mas, de fato, estórias de superação encantam pessoas há gerações, porque lhes manda um recado encorajador de que seus problemas são solucionáveis. Como crianças, queremos ouvir que, qualquer que seja o problema, "vai ficar tudo bem".

Ainda que tocante, e em muitos aspectos, redentora, " $\mathrm{O}$ Castelo de Vidro" empurra os episódios de surras e de abusos sexuais para o lado opaco da narrativa, focando toda luz em desenrolar apenas situações reiteradas e cruéis de negligência mas que, paradoxalmente, teriam contribuído para "todos" serem fortes, trabalhadores, saudáveis e persistentes. A linha é tênue, perigosa e complexa.

Jeannette "venceu", todavia parece ter vencido por ter contado para seu público uma 'versão mais palatável de sua estória, narrativa suportável para quem quer ouvir um final feliz. Ela parece ter superado a violência, pobreza, negligência e desrespeito ao seu corpo tão somente com o trabalho duro, a ascensão profissional e, durante escasso tempo, com a manutenção do seu núcleo familiar fraternal, que, entretanto, uma leitura mais atenta nos fará observar que foi afastado logo após sua entrada na universidade e de forma quase definitiva após o esfaqueamento da mãe pela irmã transtornada psiquiatricamente. É sutil mas perceptível na obra que a narradora apresenta diversos sintomas clássicos da negligência e do abuso sofrido. Sua insistência num relacionamento insatisfatório profundamente calcado na estabilidade e segurança que o primeiro esposo (cujo casamento inicia-se, nas palavras dela, sem aparentemente perceber o que dizia, como "um negócio"). Aproximadamente uma dezena de anos se perfaz numa relação iniciada com um namoro arrastado, uma divisão de apartamento motivada por questões de moradia para enfim o início do casamento de ambos. Não há praticamente referência a momentos a dois e nos momentos críticos, a presença dele não é mencionada, sugerindo mesmo a ausência física, só consubstanciada pelos aspectos econômicos de empréstimos e mesmo dos objetos existentes 
no apartamento de ambos, dos quais Jeannette parece mais zeladora que possuidora na maior parte do tempo.

Toda a luz é jogada na ascensão da narradora: Jeannette galga variadas posições enquanto se esconde dos pais que vão no encalço da família, estabelecendo de forma não explícita uma guerra de valores entre o intangível e a estabilidade financeira que Jeannette lentamente adquiriu, primeiro através do casamento, depois pela consolidação de sua carreira.

A partir daí, as dolorosas experiências são atiradas à vala comum. Ainda que rica e encantadora, a obra não encontra outro caminho a não ser encontrar a perfeita fusão psicológica de Jeannete com o estilo "desapegado" (para usar um eufemismo) dos pais com a tranquilidade da protagonista, fenômeno só possível porque ela não depende material ou psicologicamente dos pais para viver (diferentemente da irmã caçula), o que lhe permite perdoar, dimensionar e até mesmo usar os provérbios, insights e comportamento de risco dos pais como souvenires exóticos de um passado que cuidadosamente preserva-se distante para não mais recair.

Jeannette se torna, então, a heroína ideal contemporânea: um passado complexo, mas um perdão bem humorado e quase cristão, um senso de compreensão além da média e um elemento agregador de uma família que tinha tudo para dar errado e nutrir ódio e mágoa. Ela relata a ânsia de estar em movimento e os sentimentos claustrofóbicos gratuitos após o luto do pai, mas não há descrições de pesadelos noturnos, falta de confiança em si mesma ou de como conseguiu construir a ponte entre a necessidade de ter um relacionamento insatisfatório fortemente calcado na previsibilidade do primeiro marido para a relação que, nas próprias palavras dela, foi capaz de convencê-la a admitir, narrar e reconciliar-se com seu passado.

Jeannette não problematiza, soluciona. A escritora cimenta suas fissuras internas optando, ainda que de forma inconsciente, por minimizar os episódios em que sofre ou testemunha abuso sexual, demonstrando ainda uma disposição muito inferior de responsabilização dos pais do que de episódios aparentemente menos graves de negligência. Mais: como sobrevivente de abuso, contribui para a síndrome do silêncio quando absolve o pai na tentativa de deduzir, junto com os irmãos, que o pai normalizou o abuso da avó contra o neto porque ele mesmo deveria ter sido vítima. Torna-se, estranhamente, incapaz de estabelecer qualquer relação com o episódio em que o pai a tenta agenciar como distração de 
jogadores adversários no bar onde joga compulsivamente, colocando-a francamente em situação vulnerável para um estupro.

Lamentavelmente a protagonista contribui para a fetichização da figura da criança violentada que não tem danos, apenas uma enorme força interior que a redime de todo passado infeliz. Não se trata, claro de pendular para outra fetichização: a da vítima com passado insepulto, eternamente assustada para que se garanta de que afinal os abusos foram mesmo tão graves quanto ela conta. Entretanto, discursos de vitória frequentemente silenciam os pesadelos de muitos. Enquanto Jeannette ascende, Maureen, quando finalmente vive com relativa estabilidade, agora proporcionada pelo cuidado dos irmãos, vai se destruindo lentamente. Jeannette sugere, como aprendeu dos pais, a falta de fibra como razão, e alfineta a disposição da irmã de ser sustentada e protegida por namorados, o desinteresse pelo estudo, o afundamento na bebida e cigarro e por fim, a identificação com o estilo sem perspectivas dos pais. O sucesso de Brian como policial, o sonho realizado de Lori como ilustradora, a alegria de Jeannette num casamento feliz numa casa de campo e sua incursão na literatura compreendem o fecho feliz na ideia de "apesar de tudo, salvaram-se todos". Mesmo no encontro final no clássico dia de ação de graças norte americano, porém, Maureen é apenas citada como a irmã que está na Califórnia e "pretende visitar-nos dia desses". Não há indicações de seu estado mental, manutenção econômica ou superação dos episódios com os pais. Maureen é afinal a Jeannette que não deu certo.

\section{5- CONSIDERAÇÕES FINAIS}

O Castelo de Vidro é uma obra que apresenta evidência contemporânea, sendo transformada em película e aumentando seu alcance. Certamente um dos aspectos mais interessantes jurídicos da obra é a ausência do Estado para a prevenção e cessamento das situações de negligência, bem como a omissividade dos pais e mesmo cumplicidade parcial no caso dos abusos físicos e sexuais. Nenhuma das crianças chega a ser ouvida de fato e, de certa forma, a superação da protagonista e o escamoteamento proposital dela, apoiando-se tão somente em seus irmãos e mascarando a situação, de certa forma, contribui ainda que involuntariamente para a ideia que a coragem e a força é capaz de permitir que crianças abusadas podem encontrar seus rumos sozinhas, bastando disciplina e persistência na busca de sucesso que lhe dê estabilidade para sair da situação. 
Nessas circunstâncias, torna-se ainda mais evidente que Jeannette e seus irmãos optaram pela não intervenção do estado, possivelmente pela recusa ao processo comum de revitimização enfrentado no sistema. A atitude da narradora de escolher partes de seu relato em detrimento de outras, bem como limitar-se surpreendentemente a descrever a fala de seus pais quando rejeitavam a importância de suas tentativas de denúncia, riscando por completo a descrição de como se sentia; aparentemente sinalizou que ela compreendeu que seu relato não era importante para caracterizar a sua trajetória, contribuindo involuntariamente para a síndrome do segredo, em forma secundária de rejeição narrativa mais detalhada ou crítica destes episódios.

O grupo Sobreviventes de Incesto Anônimos destaca com propriedade que um dos desafios é a percepção de que as vítimas não seduziram o abusador. Mais: deixa claro que coação física raramente é necessária com uma criança, uma vez que ela já fíca intimidada diante a possibilidade do abuso, e que, sem sombra alguma de dúvidas, "quanto mais gentil o ataque, mais culpa inapropriada a vítima carrega”. Por mais trágica que seja o abuso sexual de crianças e adolescentes sob violência física, esta proporciona em parte à vítima alguma convicção de que não havia alternativa ou clareza do seu não consentimento. Às vítimas abusadas com gentileza ou através de persuasão atormenta não apenas a culpa pelo abuso, mas a culpa sobre si mesma, de não ter sido suficientemente corajosa ou forte para negar aquela situação ou denunciá-la de forma eficiente. Entre diversos sintomas físicos e psicológicos listados, a SIA enumera entre os últimos a personalidade dissociativa (capacidade de "esvair-se de um lugar, não estar presente), a rejeição ao toque afetivo exceto para fins sexuais, rejeição a figuras de autoridades, como dificuldade de confiar em profissionais de saúde, em especial de imobilizar-se para exames físicos; traumas com portas abertas ou fechadas, lacunas de memória, dificuldades respiratórias de ordem psicológica e frequentemente problemas alimentares, excesso ou abstinência de alimentação, com acréscimo de diferentes distúrbios na área.

Dos sintomas, porém, o mais repetitivo é a dificuldade de confiar em si e em outras pessoas. Enquanto Jeannette é aplaudida, portanto, por confiar tão encasteladamente em si mesma, passa ao largo da estória estabelecer o caminho trilhado para refazer seus laços fraternos, criar novos, e o que foi feito da irmã que estilhaçou o próprio castelo. 


\section{6- REFERÊNCIAS}

BORBA, Maria Rosi de Meira. O duplo processo de vitimização da criança abusada sexualmente: pelo abusador e pelo agente estatal, na apuração do evento delituoso. Disponível em: < http://jus2.uol.com.br/doutrina/texto.asp?id=3246 >. Acesso em: 04 de agosto de 2017.

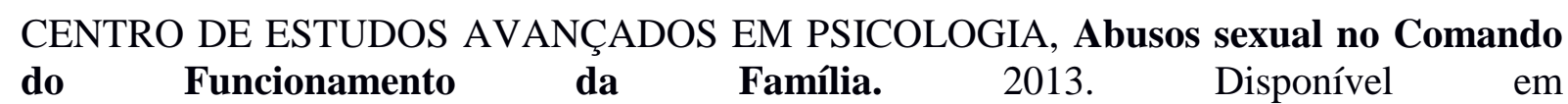
$<$ http://blog.cicloceap.com.br/abusosexual-no-comando-do-funcionamento-da-familia/>.

Acessado em 12 de agosto de 2017.

FAIMAN, Carla Júlia Segre. Abuso sexual em família: a violência do incesto à luz da psicanálise. São Paulo: Casa do Psicólogo, 2004.

FURNISS, Tilman. Abuso Sexual da Criança: uma abordagem multidisciplinar. Porto Alegre; Artes Médicas, 1993.

SCHREIBER, Elizabeth. Os Direitos Fundamentais da Criança na Violência Intrafamiliar. Porto Alegre: Ricardo Lenz, 2001.

SIA. Sintomas de um sobrevivente de incesto. Disponível em <http://www.siabr.org/index.html>. Acessado em 12 de agosto de 2017.

ZAVASCHI, Mari Lucrécia Scherer et al. Abuso sexual na infância: um desafio terapêutico. Revista de Psiquiatria, São Paulo, $\mathrm{n}^{\circ} 13$, p. 136-145, set./dez. 1991. 